UPPSALA UNIVERSITET

Working Paper 2007:17

Department of Economics

\title{
Monetary Policy and Swedish Unemployment Fluctuations
}

Annika Alexius and Bertil Holmlund 
Department of Economics

Working paper 2007:17

Uppsala University

June 2007

P.O. Box 513

ISSN $1653-6975$

SE-751 20 Uppsala

Sweden

Fax: $+{ }_{4} 6184711478$

Monetary Policy and Swedish Unemployment Fluctuations

Annika Alexius And Bertil Homlund

Papers in the Working Paper Series are published on internet in PDF formats.

Download from http://www.nek.uu.se

or from S-WoPEC http://swopec.hhs.se/uunewp/ 


\title{
Monetary Policy and Swedish Unemployment Fluctuations ${ }^{\#}$
}

\author{
by
}

\author{
Annika Alexius* and Bertil Holmlund ${ }^{\S}$
}

This draft: June 18, 2007

\begin{abstract}
A widely spread belief among economists is that monetary policy has relatively short-lived effects on real variables such as unemployment. Previous studies indicate that monetary policy affects the output gap only at business cycle frequencies, but the effects on unemployment may well be more persistent in countries with highly regulated labor markets. We study the Swedish experience of unemployment and monetary policy. Using a structural VAR we find that around 30 percent of the fluctuations in unemployment are caused by shocks to monetary policy. The effects are also quite persistent. In the preferred model, almost 30 percent of the maximum effect of a shock still remains after ten years.
\end{abstract}

Keywords: Unemployment, Monetary policy, structural VARs JEL classification: J60, E24.

\footnotetext{
\# Paper prepared for the Symposium on “The Phillips curve and the Natural Rate of Unemployment”, Kiel Institute for the World Economy, 3-4 June 2007.

* Department of Economics, Uppsala University, Box 513, SE-751 20 Uppsala, Sweden. Annika.Alexius@nek.uu.se

${ }^{\S}$ Department of Economics, Uppsala University. Box 513, SE-751 20 Uppsala, Sweden. Bertil.Holmlund@nek.uu.se
} 


\section{Introduction}

The effects of monetary policy shocks on the output gap are relatively well documented. The response of the output gap is hump shaped with the peak occurring between four and six quarters after a shock. By the definition of the output gap, the effect then disappears within the business cycle. Given Okun's law, movements in output can be directly translated into movements in unemployment. The actual reaction of unemployment to monetary policy shocks is however poorly documented and it is not clear whether it really is a mapping of the effects on the output gap. In particular, while U.S. unemployment can reasonably be characterized as a mapping of the output gap, this is arguably not true of unemployment in most European countries.

In this paper we analyze the effects of monetary policy on unemployment in Sweden. Specifically we investigate how much of the fluctuations in unemployment that are caused by monetary policy shocks and how persistent these effects are. Answers to these two questions are obtained from a structural VAR model. Variance decompositions show which shocks that have caused movements in a variable during the sample period and impulse response functions contain information about the magnitude and duration of the effects of a specific structural shock.

Although the effects of monetary policy on unemployment are not as well documented as one might imagine, there is a handful of previous studies of the issues at hand. Ravn and Simonelli (2006) estimate a twelve-variable VAR on U. S. data and study the effects of four structural shocks, including monetary policy, on several labor market indicators. They find that (i) the response of labor market variables to monetary policy shocks is hump shaped, (ii) between 15 and 20 percent of the variance in unemployment is caused by monetary policy shocks, and (iii) the maximum effect of a shock occurs after 4-5 quarters.

The sources of movements in unemployment have been studied using variance decompositions in several papers, including Dolado and Jimeno (1997), Jacobsson et al (1997), and Carstensen and Hansen (2000). Dolado and Jimeno analyze Spanish unemployment and conclude that the main source of unemployment variability is productivity shocks (37 percent), while labor 
supply shocks and demand shocks account for 25 percent each. Carstensen and Hansen (2000) find that technology shocks and labor supply shocks account for most long-run fluctuations in German unemployment but that goods market shocks are important in the short run. Similar results are found for Italy by Fabiani et al. (2001). Jacobson et al (1997) find that transitory labor demand shocks have negligible effects on unemployment in the Scandinavian countries. ${ }^{1}$ Maidorn (2003) on the other hand find that demand shocks account for 40 percent of the tenyear fluctuations in Australian unemployment and Gambetti and Pistoresi (2001) find permanent effects of demand shocks on Italian unemployment that account for almost 60 percent of the ten-year fluctuations. These papers do not identify shocks to monetary policy separately but the total results for demand shocks can be interpreted as an upper bound for the influence of monetary policy. Karanassou et al. (2005) and Christoffel and Linzert (2005) among others document persistent effects on European unemployment rates using other approaches than VAR models. Jacobson et al. (2003) actually document permanent effects of monetary policy on Swedish unemployment, but they model the rate of unemployment as an I(1) process whereby all shocks automatically have permanent effects. Algan (2002) finds that the standard model works well for the U.S. but fails to capture the rise of French unemployment. Amisano and Serati (2003) conclude that demand shocks have persistent effects on unemployment rates in several European countries. In their SVAR, the effect of a demand shock dies out in 13-17 quarters in the investigated European countries, compared to 7 quarters in the U.S.

This paper differs from previous studies in several respects. First, the demand side of the economy is modeled in a more elaborate fashion. We allow for three different kinds of demand shocks, viz. monetary policy, fiscal policy, and foreign demand. The finding in previous work that demand shocks are unimportant to unemployment fluctuations may well be a consequence of the rudimentary modeling of the demand side of the economy. Our results indicate that around 30 percent of the fluctuations in unemployment are caused by shocks to monetary policy. The effects are also quite persistent. In the preferred model, more than 30 percent of the maximum effect of a shock still remains after ten years.

\footnotetext{
${ }^{1}$ Their data series end in 1990 and thus exclude Sweden’s turbulent experiences during the 1990s.
} 
The paper unfolds as follows. Section 2 gives an account of the Swedish unemployment experience and macroeconomic policies over the last couple of decades. Section 3 discusses model specifications, section 4 describes the data and section 5 presents the main results. Section 6 includes extensive robustness checks and section 7 concludes.

\section{Unemployment and Macroeconomic Policies in Sweden ${ }^{2}$}

\subsection{Stabilization Policy in Turmoil}

For most of the $20^{\text {th }}$ century, Sweden pursued a fixed exchange rate policy. After the breakdown of the Bretton Woods system in 1973, the Swedish krona was first pegged to the D-mark (via the “currency snake”) and from 1977 to 1991 to a trade-weighted basket of foreign currencies. A crucial requirement for the feasibility of the fixed-exchange regime was, of course, that domestic inflation was kept in line with inflation abroad. This turned out to become increasingly difficult and a series of devaluations took place in the late 1970s and the early 1980s. These devaluations resulted in substantial (albeit temporary) improvements in competitiveness that counteracted the adverse employment effects of unsustainable inflation. The large devaluations in the early 1980s paved the way for an employment expansion that lasted throughout the decade, reinforced by an international upswing as well as expansionary domestic policies. However, the expansionary domestic policies during the 1980s carried the seeds that ultimately led to a complete regime shift in stabilization policy in the early 1990s.

The credit market was one important source of domestic demand expansion. By the end of 1985, Swedish financial markets had been largely deregulated. Restrictions on household loans in commercial banks and credit institutions had been lifted, which set in motion a rapid increase in bank loans to the household sector. This change took place during a period when marginal tax rates were generally high and when mortgage payments were deductible in income taxation. The interaction of financial deregulation, progressive taxes and generous rules for deducting interest payments created the preconditions for a strong credit expansion. The total credit volume increased at an annual rate of almost 20 percent during 1985-1990. The consumption boom that followed involved a fall in the household saving rate to minus 5 percent of disposable income in 1988 and a gradual build-up of household debt.

\footnotetext{
2 This section draws heavily on Holmlund (2003).
} 
The surge in aggregate demand contributed to a fall in unemployment along with a gradual increase in inflation. By the end of the 1980s, unemployment was approaching 1 percent of the labor force. Monetary policy was tied to defending the fixed exchange rate and fiscal policy was too lax to prevent the rise in inflationary pressure.

During the late 1980s, a government committee developed a far-reaching proposal for reform of the Swedish tax system. Key elements were lower marginal tax rates on labor earnings and the introduction of a dual system of income taxation with a 30 percent tax rate on income from capital. Mortgage payments could then be deducted at 30 percent. These reforms were put into practice in 1990 and 1991 and caused a marked increase in after-tax real interest rates. The demand for owner-occupied housing fell predictably; between 1990 and 1993, the fall in real prices amounted to 30 percent. On top of this, the household saving rate rose from minus 5 percent in 1988 to plus 7 percent in 1992. The rise in saving reflected households' attempts to bring down a debt-to-income ratio that had shown a marked increase over the 1980s, especially during the second half of the decade.

In this environment, Swedish stabilization policy took close to a U-turn. The prime objective for decades had been full employment, although the desirability of low inflation was recognized in words. In practice, this has led governments to undertake several devaluations in the late 1970s and the early 1980s so as to restore competitiveness that had been eroded by high inflation and fixed exchange rates. In the early 1990s, the government declared that low inflation was the prime objective of stabilization policy. A unilateral affiliation of the krona to the ECU was declared in May 1991. The stated intention was to rule out future devaluations as escape routes from unsustainable inflation and loss of competitiveness.

In addition to self-inflicted wounds, Swedish policy making was also hit by bad luck in the early 1990s. An international recession struck during the first years of the decade. Industrial production declined between 1990 and 1993 by 4-5 percent in the EU area and by over 6 percent in Germany. The general weakening of major Swedish export markets added to the falling demand for Swedish exports and reinforced the sharp decline in GDP. 
During the fall of 1992, the krona was put under a number of speculative attacks and it became increasingly doubtful whether the fixed exchange rate was sustainable. The real exchange rate was overvalued with between 10 and 20 percent, creating severe difficulties for the export sector. In order to defend the fixed exchange rate, the central bank kept a high short-term interest rate throughout 1992 and raised it to 500 percent in September. Given inflation rates around two percent, also the real interest rate was extremely high during this period. In November 1992, the fixed exchange regime had to be abandoned and the krona was floating. A new monetary regime was established, including an inflationary target (from early 1993) and a more independent central bank (from the late 1990s).

The chronological tale told so far emphasizes two main policy failures. First, it is clear that fiscal policy was too lax in the second half of the 1980s. The fixed exchange rate target had tied the hands of monetary policy and only fiscal policy tools were available to combat rising inflationary pressure. Second, it is also clear that the timing of financial deregulation and tax reform was less than optimal. Under more ideal circumstances, the tax reform should have preceded financial liberalization, rather than the other way around. Had the financial liberalization taken place in an environment with less favorable conditions for household loans, the effects on credit demand and private consumption would have been smaller.

These claims appear fairly uncontroversial, although the fine details of the impact of financial deregulation and tax reform are debatable. More controversial is an assessment of the policy stance vis-à-vis the emerging slump in the early 1990s. A less stubborn defense of the krona would presumably had cushioned the downturn and led to a less dramatic rise in unemployment.

\subsection{The Evolution of Unemployment and Nonemployment}

The Swedish unemployment rate displayed modest fluctuations around an average level of 2 percent during the 1960s, the 1970s and the 1980s. ${ }^{3}$ A weak trend increase in unemployment

\footnotetext{
${ }^{3}$ These are unemployment figures from the Swedish labor force surveys. The Swedish definition of unemployment differs slightly from unemployment as defined by the International Labour Organisation (ILO). In particular, students engaged in fulltime job search are classified as unemployed by ILO but as out of the labor force in the national definition. We will discuss alternative unemployment measures as we proceed.
} 
could be identified, however. The recession of the early 1970s entailed higher unemployment than what was observed during the 1960s. Likewise, the early 1980s witnessed a recession where unemployment approached 4 percent, a level considered as exceptionally high by the standards of the 1960s and the 1970s. However, by the end of the 1980s the unemployment rate had reached a decade low of 1.1 percent (June 1989).

The three decades from the early 1960s to the late 1980s also involved sharply rising female participation rates. In 1965, female participation in the labor force stood at 54 percent; in 1989 it had risen to 82 percent. Male participation rates fell only modestly - from 89 to 86 percent between 1965 and 1989 - and the aggregate labor force participation rate thus rose dramatically. Employment increased in tandem with the increase in participation. By the late 1980s, employment-to-population rates stood at 85 and 81 percent for males and females, respectively.

The slump of the early 1990s involved a fall in the level of GDP from peak to trough by 6 percent and produced an unprecedented increase in unemployment. Between 1990 and 1993, unemployment rose from 1.5 percent to 8.2 percent. The increase in unemployment was accompanied by a sharp decline in labor force participation among both men and women. The total decline in employment in the early 1990s amounted to around 500000 persons, or a fall in the employment-to-population rate from 83 percent to 73 percent between 1990 and 1993.

Over the period 1993 to 1997, the unemployment rate hovered around 8 percent whereas employment fell slightly (reaching 70.7 percent of population in 1997). However, a strong rebound began in 1997 and involved a rise in GDP growth and employment as well as a substantial fall in unemployment. By 2001 the unemployment rate had fallen to 4 percent and the employment-to-population rate had increased to 75 percent.

The evolution of unemployment according to several measures is displayed in Figure 1. The gap between "ILO unemployment" and the national measure consists of full-time students searching for a job. The ILO rate hit 10 percent in 1996 and 1997 and had fallen to 5 percent in 2001. An extended measure of unemployment includes also those "latent job seekers" who are 
jobless, willing and able to work but do not meet the search criteria for being classified as unemployed. ${ }^{4}$ This extended unemployment rate hit 12-13 percent in the mid-1990s and had fallen below 7 percent by 2001 .

Rising unemployment is clearly only one part of the increase in nonemployment, the other being rising nonparticipation. Figure 2 shows how a very broad measure of unemployment nonemployment - has evolved over time; nonemployment is simply one minus the employment-to-population rate. The 1970s and the 1980s exhibited a trend decline in nonemployment which largely reflected rising female labor force participation. This trend was sharply broken when the slump of the early 1990s hit the Swedish economy. The increase in nonemployment has turned out to be largely persistent. However, part of the increase in nonemployment is driven by enhanced educational opportunities provided by government policies, including an expansion of higher education and initiatives to foster adult education.

A significant fraction of nonparticipation involves "inactivity" associated with early retirement, receipt of disability pensions and long-term sickness. Information on these categories is not available on a consistent basis in the labor force surveys. There is nevertheless strong evidence, from the labor force surveys and other sources, that nonparticipation for various disability and sickness-related reasons has increased over the 1990s.

\subsection{Monetary and Fiscal Policy after the Slump}

When the krona was left to float in November 1992, it depreciated immediately and by the end of 1992 it had fallen by 15 percent against the ECU. Competitiveness was restored to a level comparable to the situation after the devaluation in 1982. The improved competitiveness as well as stronger market growth brought about a rise in exports. Between 1993 and 1995, manufacturing output increased by over 20 percent and manufacturing employment by around 15 percent. Despite this marked rebound, the overall effect on employment was initially negligible because of negative contributions to growth from private and public consumption.

\footnotetext{
${ }^{4}$ The latent job seeker category comprises also full-time students (including persons in labor market training) that search for employment.
} 
Figure 1. Unemployment in Sweden, 1970-2005.

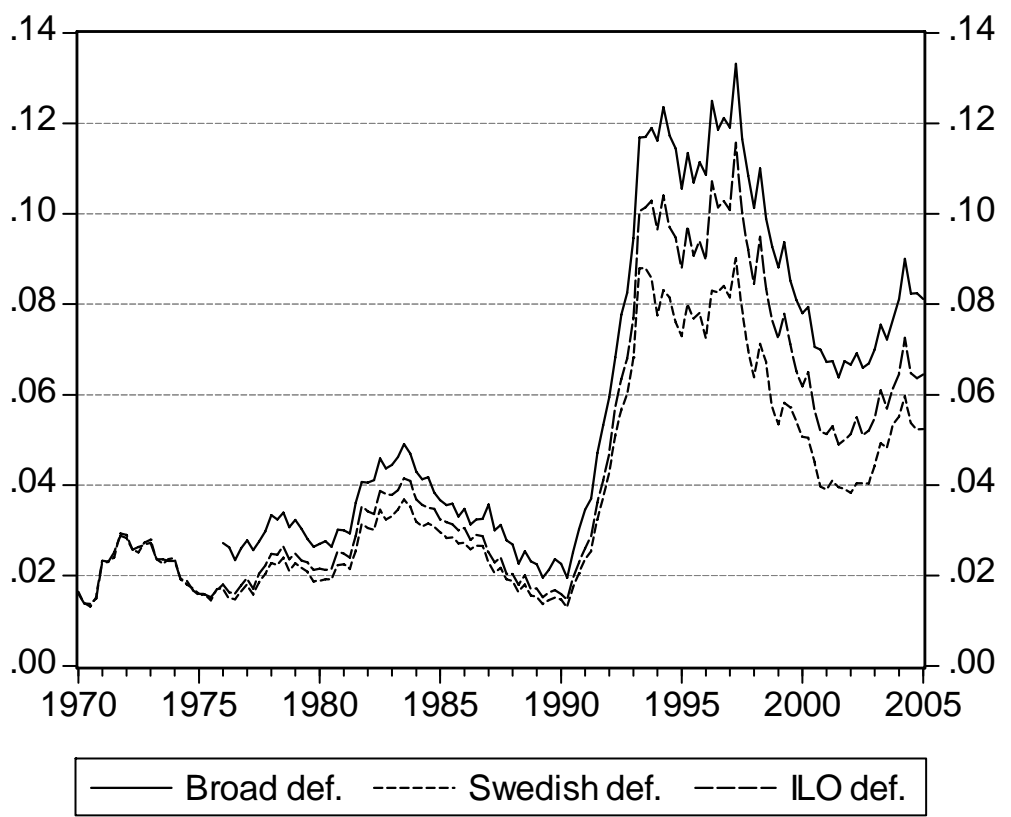

Notes: The ILO-definition includes full time students search work; the Swedish definition does not. Broad unemployment includes also "latent job searchers". The unemployment rates are measured relative to the labor force, where the labor force are adjusted so as to reflect the various unemployment concepts. The age groups are 16-64.

Source: Labor force surveys, Statistics Sweden.

Figure 2. Nonemployment in Sweden, 1970-2005.

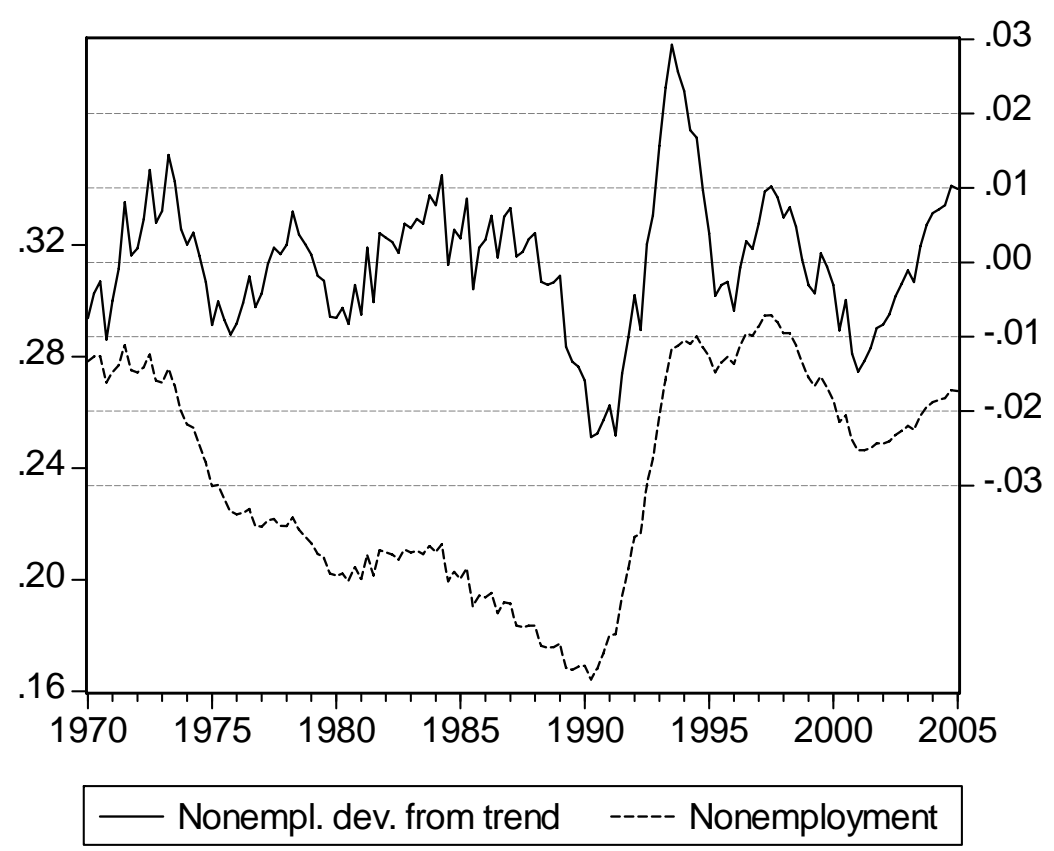

Notes: Nonemployment (left axis) is measured as (1-employment/population). Trend nonemployment is estimated by a Hodrick-Prescott filter. The age groups are 16-64.

Source: Labor force surveys, Statistics Sweden. 
In early 1993, the central bank announced a strategy of inflation targeting. The goal of monetary policy should be to stabilize annual consumer price inflation at 2 percent, with a margin of tolerance of \pm 1 percentage point. A new amendment to the central bank legislation, in force from 1999, gave the central bank greater independence from direct political influence. A new executive board consisting of six full-time members was made responsible for monetary and exchange rate policies.

By and large, the new framework for monetary policy has been successful in achieving its main goal. Inflation has stayed within the tolerable band for most of the time and a credible low inflation regime has been established. The average annual rate of consumer price inflation has been 1.6 percent over the period 1993-2002, thus undershooting the inflation target. But the low inflation regime did not materialize without costs. Available survey-based estimates of inflation expectations from around 1995 indicated that the low inflation target was far from universally credible. According to some measures, expectations of medium-term inflation hovered around 4 percent. These stubborn inflation expectations triggered a series of central bank interventions to establish its non-inflationary credentials. The repo rate (the main signaling rate) was raised in steps between 1994 and 1995, reaching close to 9 percent in the second half of 1995. These policies appeared to be effective as inflation as well as inflation expectations fell over the next couple of years and paved the way for a series of repo rate reductions during 1996.

Whether the successful conquest of inflation has been good or bad for employment remains an open question. The generally restrictive monetary policy of the mid-1990s probably delayed the economic upswing although it may have been necessary in order to secure credibility for the low inflation target. A more controversial issue is whether the new monetary policy framework is employment-friendly or not. There are pros and cons in this matter. On the pros side, it can be argued that a more independent central bank strengthens incentives for wage moderation. On the cons side, an ambitious price stabilization target may arguably be in conflict with ambitious employment goals in the presence of nominal rigidities as emphasized by Akerlof et al (1996, 2000). 
When the slump hit the economy, the government's budget deficit rose sharply and by 1992 the budget deficit for the consolidated public sector stood at 12 percent of GDP. The government's debt-to-GDP ratio amounted to 76 percent by the end of the year. The need to bring government finances under control became a top priority for the new (social democratic) government in 1994. The following years involved a major effort to stabilize government debt and to reduce the budget deficit. The program entailed expenditure cuts, especially concerning transfers, as well as tax increases. The policies were resoundingly successful in terms of the stated objectives: by the end of the decade, the government's budget deficit was eliminated and the debt-to-GDP ratio had declined to 60 percent.

The generally contractive fiscal policy is presumably one reason why unemployment remained stubbornly high in the mid-1990s. However, the fiscal consolidation added credibility to the anti-inflationary stance of macroeconomic policy. Fiscal policies were eased to support growth of private and public consumption as the budgetary goals were met and absent any visible threat to the low inflation target.

One ingredient of the fiscal consolidation was the introduction in 1996 of a new system for decisions on government expenditure. The goal was to establish a long-term approach to expenditure decisions. The key innovation involved three-year nominal expenditure ceilings. In year 1997, say, decisions should be taken on expenditure for 1998, 1999 and 2000. To some degree, this system tied the hands of fiscal policy, although some room was left for discretionary policies. This reform was followed by a decision to set a goal for the general government budget surplus of 2 percent of GDP as an average over the business cycle.

Summing up, several sources of movements in Swedish unemployment can be identified. Monetary policy was extremely contractionary during most of 1992, with the nominal interest rate hitting 500 percent at the same time as the real exchange rate was overvalued. Fiscal policy was contractionary in the mid-1990s and probably expansionary in the late 1990s. International business cycle movements almost certainly have had substantial effects on the small open Swedish economy. We will in the remaining part of the paper make use of a small structural 
VAR model to disentangle how various shocks can account for the Swedish unemployment experience.

\section{Model Specification}

\subsection{The VAR Approach}

Unemployment is conceivably affected by a very large number of factors such as labor supply, productivity, foreign demand, fiscal policy, international competitiveness, oil price shocks, etc. In order to analyze the effects of monetary policy, these other variables have to be taken into account as well. However, a structural VAR model quickly becomes cumbersome as the number of included variables increases. The number of parameters to be estimated increases with the number of lags times the number of endogenous variables, while the length of available time series restricts the possible number of observations. Furthermore, the number of theoretically sensible identifying assumptions to separate the different structural shocks also increases with $n(n-r) / 2$, where $n$ is the number of endogenous variables and $r$ is the number of cointegrating relations (possibly zero). We have to choose a reasonably small set of variables that still covers as much as possible of the movements in unemployment that are unrelated to monetary policy. Unemployment itself and a measure of monetary policy are self-evident, as is foreign demand for a small open economy like Sweden. Any foreign variables can be assumed to be exogenous, which facilitates identification and saves degrees of freedom. Based on results from the previous studies discussed above, domestic demand, productivity, and fiscal policy are also major sources of movements in unemployment. This yields six variables, three of which will be modeled as exogenous.

Several different methods of identification are available within the VAR literature. In a seminal article by Blanchard and Quah (1989), restrictions are imposed on the long-run effects of shocks. For instance, productivity shocks are separated from demand shocks by assuming that demand shocks do not affect real output in the long run while productivity shocks do. Alexius and Carlsson (2005) show that this long-run restriction works well in the sense that the identified technology shocks are highly correlated with refined Solow residuals in Swedish data. In Sims (1980) identification is achieved using short-run restrictions on the timing of the effects of shocks only. For instance, monetary policy shocks are frequently identified by 
assuming that a change in the interest rate does not affect inflation in the same period since prices are sticky and respond with a delay. We believe that a combination of the two approaches yields the most convincing identification in this context. In an $n$-variable system a total of $n(n-1) / 2$ restrictions are needed for exact identification after imposing an identity covariance matrix of the structural shocks.

We start with the $\operatorname{VMA}(\infty)$ form of the reduced form estimation

$$
x_{t}=A(L) e_{t}
$$

where $A(L)$ is the inverted lag polynomial from the reduced form estimation and $e_{t}$ denotes the reduced form residuals. Then, assume that the structural form $\operatorname{VMA}(\infty)$ can be written as

$$
x_{t}=C(L) \varepsilon_{t}
$$

where $C(L)$ is the structural counterpart to $A(L)$ above and $\varepsilon_{t}$ are the structural shocks. Equating the two representations of the system in (2) and (3) and manipulating we get

$$
C(1)=A(1) C_{0}
$$

where $C(1)$ is the long-run VMA impact matrix of the structural shocks, $A(1)$ the estimated $\operatorname{VMA}(\infty)$ from the reduced form estimation stage and $C_{0}$ the short-run matrix defining the reduced form shocks as linear combinations of the structural shocks. This short run impact matrix is all we need for further analysis through impulse response functions and forecast error variance decompositions since it traces out the effects of structural shocks to the variables.

\subsection{Measuring Monetary Policy}

During the first part of the sample Sweden participated in a sequence of fixed exchange rate arrangements. In November 1992 the fixed exchange rate was abandoned and Swedish krona was instead allowed to float. When the sample period covers both fixed and floating exchange 
rate regimes, we either have to split the sample and estimate two different models using different variables to represent monetary policy, or construct a single time series that captures the effects of monetary policy on the economy in both regimes. The largest monetary policy shocks during the period occurred in 1992 as the Riksbank increased the interest up to 500 percentage points in order to defend the overvalued fixed exchange rate. This is a major interest rate shock during the fixed exchange rate period that would not be captured by an exchange rate variable alone. We solve this dilemma by using a so called monetary conditions index (MCI) that captures the total effect on the economy of the exchange rate and the interest rate. ${ }^{5}$

An MCI is a weighted average of the real interest rate and the real exchange rate, where the weights depend on the relative effects of the two variables on demand. The typical weight is around three to one for the interest rate relative to the real exchange rate, implying that one percentage point higher (real) interest rate has three times as large effect on aggregate demand as a real exchange rate appreciation of one percent. The Riksbank used an MCI for several years after the floating of the Krona, with a relative weight of 2.4 to 1 estimated on Swedish data. For our sample period, the relative effect of the real interest rate versus the real exchange rate on demand has changed over time. This is not surprising given the changes in the economic environment that have occurred. Swedish capital markets were deregulated during the second part of the 1980s. Market interest rates barely existed and certainly did not constitute market clearing prices prior to $1985-87$ as credit was allocated using quantity regulations rather than market prices. During the recent float, movements in exchange rates have instead had relatively small effects on demand, possibly due to the fact that changes in a floating exchange rate are perceived as less permanent than devaluations of a fixed exchange rate. In the baseline specification we use time-varying weighting parameters estimated using a seven-year window and then smoothed. MCIs constructed using constant estimated coefficients and standard coefficients (3 to 1) are included in the robustness section. Both the real exchange rate and the real interest rate are deviations from a linear trend.

Figures 3a and 3b show the short-term real interest rate and the real effective exchange rate, each along with two different measures of monetary policy. Total monetary policy or the

\footnotetext{
${ }^{5}$ This measure has been used by, among others, Bank of Canada, as operational target of policy.
} 
Figure 3a. Real interest rate and MCI.

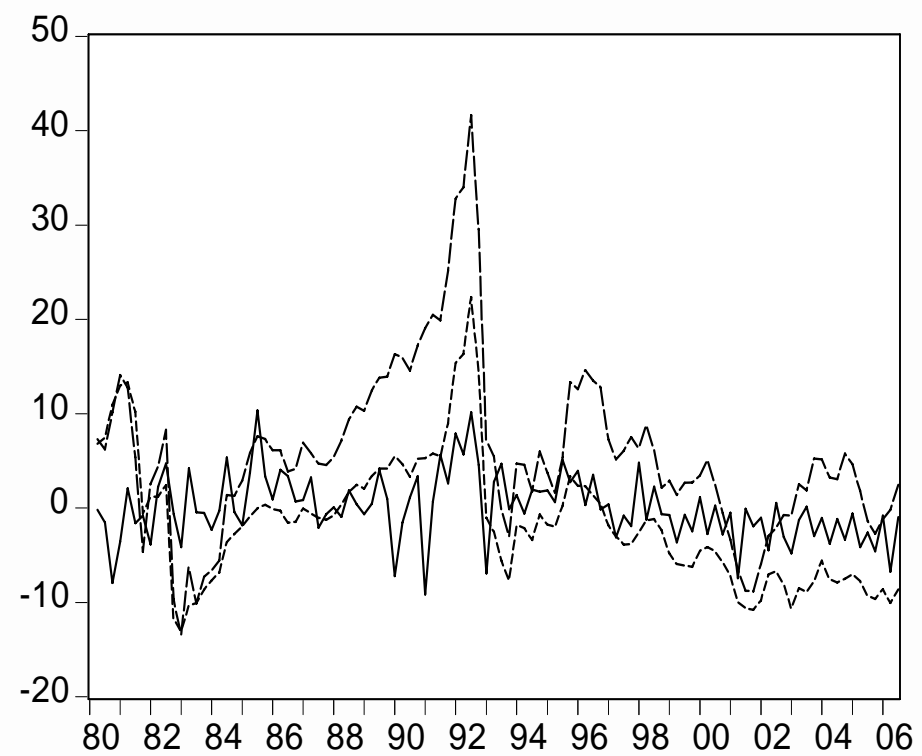

- Real interest rate, deviation from trend $\mathrm{MCl}$, time-varying coefficients

$\mathrm{MCl}$, constant coefficients

Figure 3b. Real exchange rate and MCI.

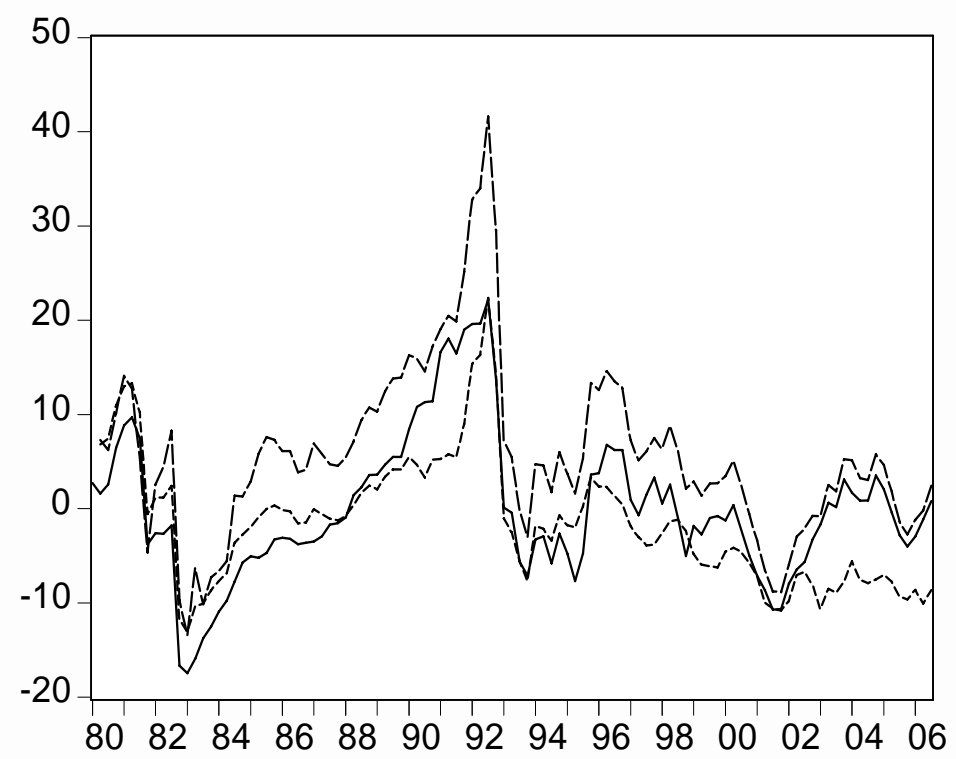

_ Real exchange rate, deviation from trend $\mathrm{MCl}$, time-varying coefficients $\mathrm{MCl}$, constant coefficients 
combined effect of the real interest rate and the real exchange rate was much more contractionary during and up the 1992 crisis than either variable on its own.

\subsection{Included Variables and Identification}

Our baseline specification includes three endogenous and three exogenous variables. The domestic output gap, unemployment, and monetary policy are modeled as endogenous. The exogenous variables are foreign output gap, productivity shocks, and a measure of the structural budget deficit. We tried to include observed fiscal policy in the model but the effects of this variable on the output gap and unemployment were consistently estimated with the wrong sign, i.e. expansionary fiscal policy decreased the output gap and increases unemployment. A possible reason for this counterintuitive result is the strong co-movement of the budget deficits and unemployment during the deep recession of the early 1990s; as noted above, the consolidated public sector's budget deficit stood at 12 percent of GDP in 1992 while unemployment soared. This should be captured as effects on the budget of unemployment and the output gap, but as these effects appear to be non-linear far away from equilibrium, they may spill over into the estimated effect of fiscal policy on activity. Indeed we have to include the output gap squared to remove cyclical effects from fiscal policy in a separate VAR. ${ }^{6}$

Since we cannot separate real output into a demand driven output gap and a productivity driven trend within this VAR, productivity shocks are identified in a first step using the Gali (1999) two-variable VAR and included as an exogenous variable in the main model. We are hence left with three exogenous and three endogenous variables: domestic output gap (y), unemployment $(u)$, monetary policy $(M C I)$ foreign output gap $\left(y^{*}\right)$, technology $(A)$, and fiscal policy $(G)$ :

$$
x=\left[y, u, M C I, y^{*}, A, G\right]
$$

Since the three final variables are exogenous, three restrictions are needed for exact identification. Monetary policy shocks are identified by assuming that a change in the interest rate does not affect inflation and the output gap in the same period since prices are sticky and

\footnotetext{
${ }^{6}$ This is done using a two-lag, two-variable VAR with the output gap squared as an exogenous variable. Business cycles are then removed by subtracting the estimated effects of the output gap from the budget deficit to obtain our measure of the structural budget deficit.
} 
respond with a delay. There are two additional shocks in the VAR, presumably a domestic demand shock and another labor market shock (such as labor supply or wage setting). Given the absence of theoretically justified identifying restrictions we refrain from labeling these two shocks.

The number of lags in the VAR is determined using information criteria and misspecification tests. As VAR models are autoregressive, it is important to include enough lags to remove residual autocorrelation. Based on this information we have included two lags in the base-line model. There are arguments in favor of three and even four lags but we have settled for the more parsimonious specification. The robustness of the main results with respect to the lag length is investigated in Section 6.

The level of unemployment is formally non-stationary over the sample period. Given that we want to estimate the persistence of shocks rather than assume that the effects are permanent, deterministic components are added to the model in a manner that yields a stationary VAR and also a stationary unemployment rate. This can be achieved using either a deterministic time trend or an intercept dummy variable from 1992. Measures of model fit unanimously favor the deterministic trend specification. Again, models with a 1992 dummy variable and also without deterministic components are estimated in Section 6.

\section{Data}

We focus mainly on the conventional measure of unemployment, i.e., unemployment according to the ILO-criteria. As robustness checks, we also consider extended measures of unemployment, viz. (i) broad unemployment that includes latent job seekers in addition to the ILO-unemployed, and (ii) the nonemployment rate measured as one minus the employment-topopulation rate. The unemployment series are taken from the Swedish labor force surveys and seasonally adjusted using Tramo/Seats.

Real GDP is collected from Statistics Sweden and seasonally adjusted using Tramo/Seats. The output gap is obtained using a Hodrick-Prescott filter with $\lambda=10,000$. The effective real exchange rate is constructed using TCW-weights and taken from IFS, as is the three months 
nominal interest rate. The latter is deflated using seasonally adjusted (Tramo/Seats) realized inflation calculated as the percentage change of total CPI, also from Statistics Sweden. The government deficit is collected from OECD’s Main Economic Indicators. As discussed, we end up using an estimated measure of the structural budget deficit. Data on foreign real GDP (OECD 16 minus Belgium due to lack of data) are also taken from OECD’s Main Economic Indicators and weighted together to a single series using the same TCW weights as for the effective real exchange rate. The foreign output gap is then constructed using a HodrickPrescott filter with $\lambda=10,000$.

\section{Results}

\section{$\underline{5.1 \text { Estimation Results }}$}

Table 1 summarizes the estimation results. It contains the sums of the coefficients on the two lags of each variable and a Wald test for their joint significance. The signs are as expected. Expansionary monetary policy increases the output gap and decreases unemployment. Higher domestic demand shock decreases unemployment and causes contractions of monetary policy. Expansionary fiscal policy increases the output gap and decreases unemployment. Foreign demand shocks increase the domestic output gap, lower unemployment and causes contractions of monetary policy. Technology shocks decrease unemployment and also the output gap. Table 1 contains the sum of the coefficients on both lags as well as $p$-values from $F$-tests for joint significance.

\section{$\underline{5.2 \text { Impulse Response Functions }}$}

Impulse response functions trace out the path of the effects of a structural shock on a variable over time using equation (2). We are particularly interested in the effects of monetary policy shocks on the unemployment rate, shown in Figure 4a. Quantitatively these results can be interpreted as follows. A contractionary monetary policy shock of one unit or a one percentage point rise in the real interest rate results in 0.25 percentage points higher unemployment after 9 quarters. After ten years unemployment is still 0.07 percentage points higher than it would have been without the shock. As this is a stationary VAR, all shocks are temporary but monetary policy is itself persistent so the shock dies out gradually. It is well known that the 95 percent asymptotic confidence intervals shown in the graphs are unnecessarily wide but we have 
refrained from turning to 67 percent confidence intervals as is often done in the VAR literature.

Table 1. VAR estimates.

\begin{tabular}{lccc}
\hline & $u$ & $y$ & $M C I$ \\
\hline $\mathrm{L}(u)$ & 0.916 & -0.010 & 14.246 \\
& $(0.000)$ & $(0.132)$ & $(0.000)$ \\
$\mathrm{L}(y)$ & -0.166 & 0.899 & 36.915 \\
& $(0.000)$ & $(0.000)$ & $(0.000)$ \\
$\mathrm{L}(M C I)$ & $2.901 \mathrm{E}-4$ & $-2.604 \mathrm{E}-4$ & 0.813 \\
& $(0.000)$ & $(0.007)$ & $(0.000)$ \\
$y^{*}$ & $-3.927 \mathrm{E}-4$ & 0.103 & 36.169 \\
& $(0.093)$ & $(0.016)$ & $(0.000)$ \\
$A$ & $-1.017 \mathrm{E}-3$ & $7.603 \mathrm{E}-3$ & -0.181 \\
& $(0.009)$ & $(0.000)$ & $(0.637)$ \\
$G$ & -0.020 & 0.073 & -5.383 \\
& $(0.294)$ & $(0.001)$ & $(0.004)$ \\
Time trend & $7.66 \mathrm{E}-5$ & $8.72 \mathrm{E}-7$ & -0.034 \\
& $(0.000)$ & $(0.967)$ & $(0.075)$ \\
Adjusted R & & & \\
Portmanteau(12) & 0.9923 & 0.8429 & 0.9719 \\
LM(3) & & $46.409(0.115)$ & \\
Log Likelihood & & 644.50 & \\
\hline
\end{tabular}

Notes: The estimation period is 1980:1 to 2005:1. The table contains the sums of the coefficients on the two lags of each variable, $p$-values within parentheses. Wald tests for joint significance of both lags of each variable. LMtests for lower order autocorrelation and White's heteroscedasticity test (not reported) are insignificant.

As in Ravn and Simonelli (2006), the response of unemployment to monetary policy shocks is hump shaped. In our baseline model a contractionary monetary policy shock obtains its maximum effect on unemployment after 9 quarters, which is a more protracted response than in Ravn and Simonelli (2006). Half of the maximum effect has disappeared after 30 quarters and 28 percent of it still remains after ten years. This can be compared to the results in Ravn and Simonelli (2006) where a monetary policy shock reaches its maximum effect on unemployment after 5 quarters. Their estimated half live is much shorter, only 8 quarters, and none of the effect remains after ten years. In fact, their estimated impulse response returns to zero already after four years. Hence monetary policy has more persistent effects on unemployment in Sweden than in the U.S. Since also univariate models of unemployment display more 
Figure 4a. Response of unemployment to a monetary policy shock.

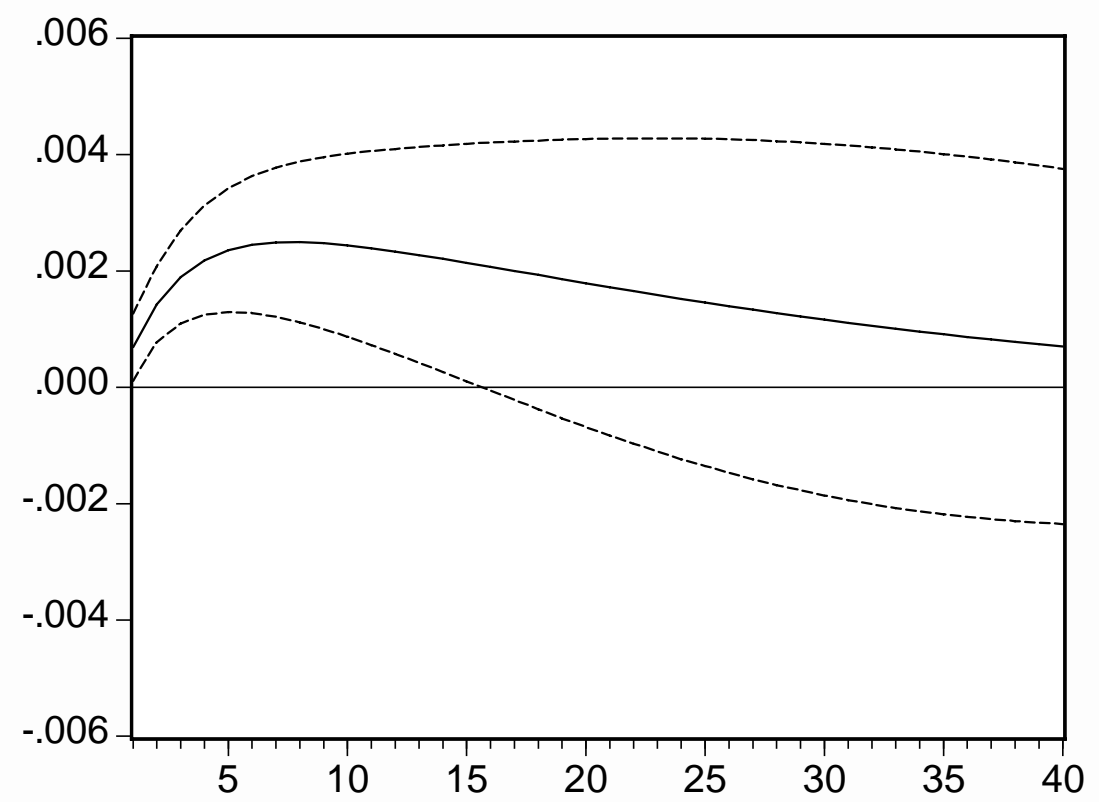

Note: Response to a temporary one percentage point increase in the real interest rate. 95 percent asymptotic confidence intervals.

Figure 4b. Response of the output gap to a monetary policy shock.

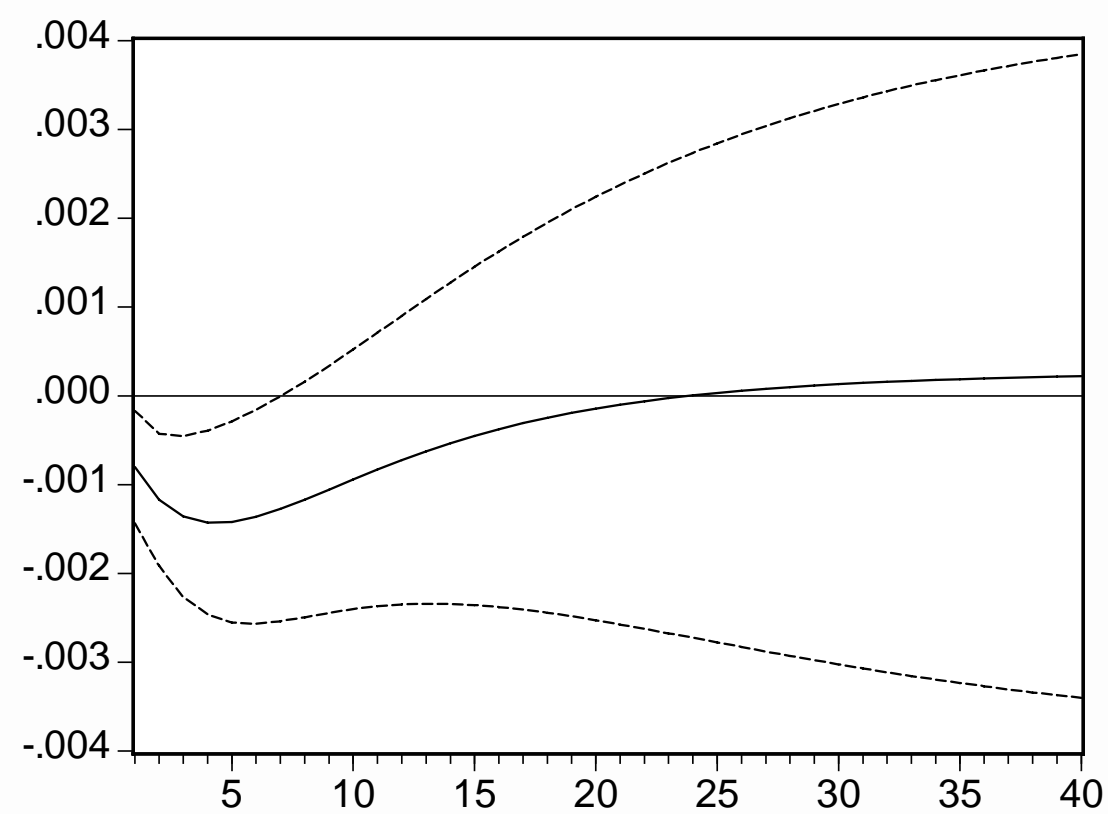

Note: Response to a temporary one percentage point increase in the real interest rate. 95 percent asymptotic confidence intervals. 
persistence in Sweden and generally Europe than in the U.S., the reason for the different results is probably found in the functioning of the labor markets rather than in factors related to monetary policy.

The response of unemployment to monetary policy can also be compared to the response of the output gap as shown in Figure 4b. These results are fairly similar to the stylized facts. The maximum effect occurs after 5 quarters, compared to 11 quarters for unemployment. Half of the maximum effect has disappeared after 11 quarters, while this takes 30 quarters in the case of unemployment. The estimated impulse response of the output gap returns to zero after 23 quarters, while the effect on unemployment still persists also after ten years.

The estimated coefficients behind the impulse response functions can be used to determine how much unemployment increased due to the contractionary monetary policy during the 1992 crisis. The total effect can be calculated by feeding the sequence of structural residuals or monetary policy shocks from 1991:4 to 1992:3 into the impulse response functions in (2). The effects on unemployment over time are shown in Figure 5. The peak occurs during 1994:4 when 5.6 percent or slightly more than half of the Swedish unemployment was due to the contractionary monetary policy during 1991-1992. If the effects up to 2005:1 are accumulated and converted to number of unemployed persons and years, this implies that about 1.6 million people (1 630 372) or 35 percent of the labor force was unemployed for one year.

\section{$\underline{5.3 \text { Variance Decompositions }}$}

Forecast error variance decompositions contain information about how much of the fluctuations in a variable that are caused by each of the structural shocks at different horizons. We are interested in the share of movements in unemployment that is due to monetary policy shocks and, in general, which shocks that have been important sources of movements in Swedish unemployment. Table 2 shows that monetary policy shocks account for 22-35 percent of the fluctuations in unemployment depending on the horizon. This is slightly more than in Ravn and Simonelli (2006), where the corresponding share was below 20 percent. 
Figure 5. Effect on unemployment to estimated monetary policy shocks 1991:4 to 1992:3.

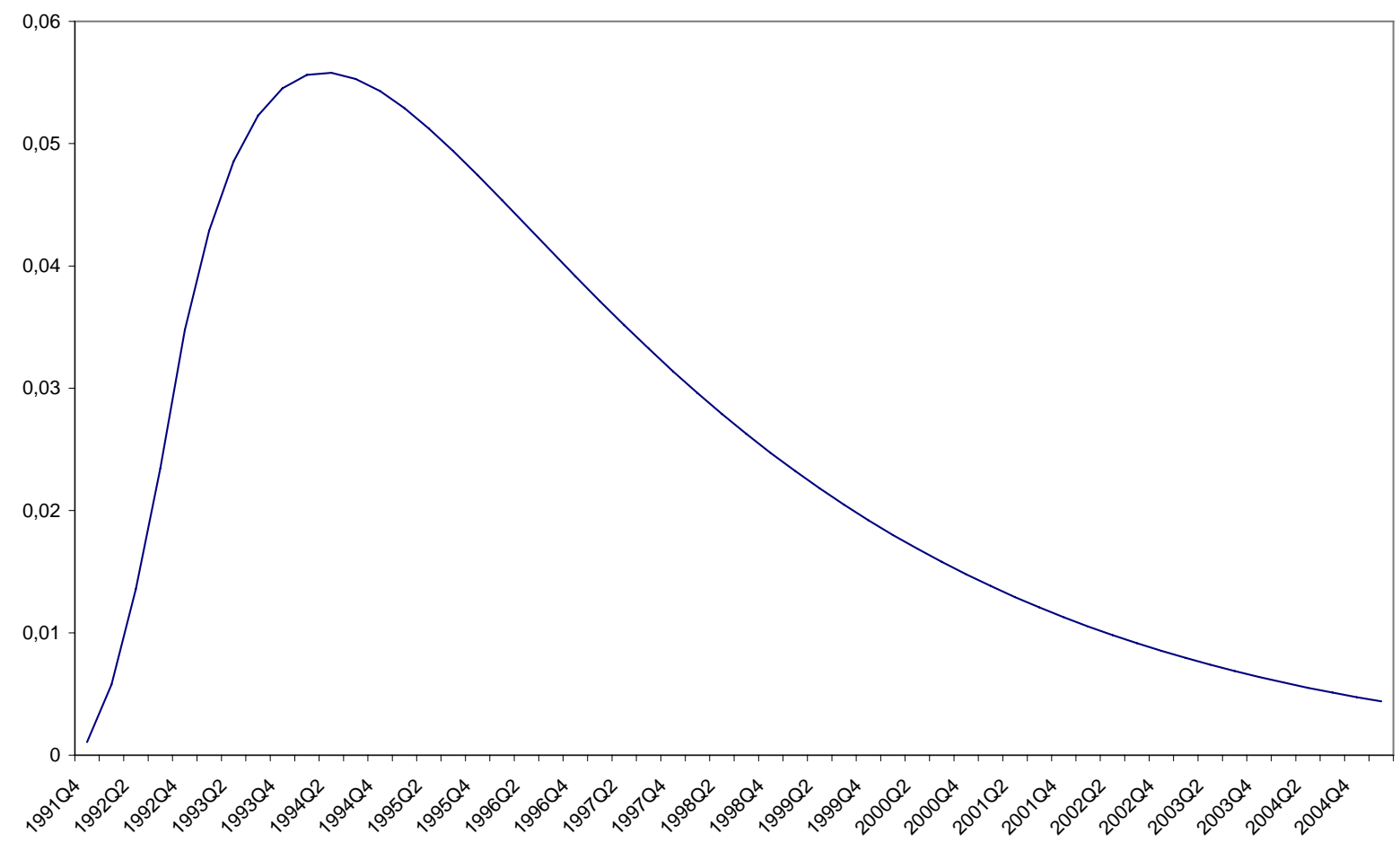

Table 2. Variance decompositions.

\begin{tabular}{lccccc}
\hline Horizon & $\begin{array}{c}\text { Foreign } \\
\text { demand }\end{array}$ & Technology & $\begin{array}{c}\text { Monetary } \\
\text { policy }\end{array}$ & $\begin{array}{c}\text { Fiscal } \\
\text { policy }\end{array}$ & Other \\
\hline 6 quarters & 7.16 & 11.58 & 22.26 & 11.09 & 47.91 \\
20 quarters & 8.55 & 13.61 & 35.49 & 15.90 & 26.45 \\
40 quarters & 7.56 & 13.61 & 34.42 & 20.69 & 23.69 \\
\hline
\end{tabular}

Composite shocks consisting of domestic demand shocks and labor market shocks such as movements in labor supply shocks account for 48 percent of the short-run fluctuations in unemployment, while the share falls to 23 percent at longer horizons. Fiscal policy and technology shocks have minor effects as they account for 10-20 percent of the fluctuations. Our results also attribute a minor role to foreign variables. The share of foreign demand shocks does not exceed 9 percent at any horizon, a finding that is robust across different specifications of the model. This can be compared to the findings in Lindé (2003), where foreign variables appear to be an important source of fluctuations in Swedish real output. Our findings indicate that this may not be true in the case of the unemployment rate. 


\section{Robustness}

Given that the model is estimated conditional on a number of specific assumptions, we devote considerable attention to investigating the robustness of the results to variations in these assumptions. Some issues appear minor but could still have potentially large effects on the results, like the number of lags in the VAR and the choice between a deterministic trend and a 1992 regime shift dummy variable. The measures of monetary policy and unemployment are in a sense more fundamental.

Figure 6 contains the impulse response functions of unemployment to monetary policy shocks in eight different specifications. First, it is clear that the effects peak later than in previous studies, after 8-12 quarters compared to five in Ravn and Simonelli (2006). The magnitude of the maximum effect varies between 0.22 and 0.41 percentage points, where the response is calculated for a shock of one standard deviation. The standard deviation of the identified monetary policy shocks typically corresponds to a real interest rate movement of two to three percent.

In absolute numbers, unemployment ten years after a contractionary monetary policy shock of one standard deviation would be between 0.025 and 0.17 percentage points higher than it otherwise would have been. The highest estimated persistence belongs to the model without dummy variable and deterministic trend and the lowest stems from the baseline specification where the MCI is constructed using coefficient of three for the real exchange rate against one for the real interest rate.

Table 3 summarizes the long-run effects of monetary policy shocks on unemployment. The results in focus are the share of monetary policy shocks in the variance decompositions of unemployment and a measure of the persistence of the effects of monetary policy shocks on unemployment. The share of monetary policy shocks in the ten-year forecast error variance decomposition of unemployment varies between 25 and 45 percent. The final column shows the share of the maximum effect of monetary policy on unemployment that remains after ten years, i.e. the impulse response after 40 quarters divided by the peak effect for each model. This is a non-robust result as the share in question varies between 8 and 38 percent. 
Figure 6. Impulse responses of unemployment to monetary policy shocks, alternative specifications.

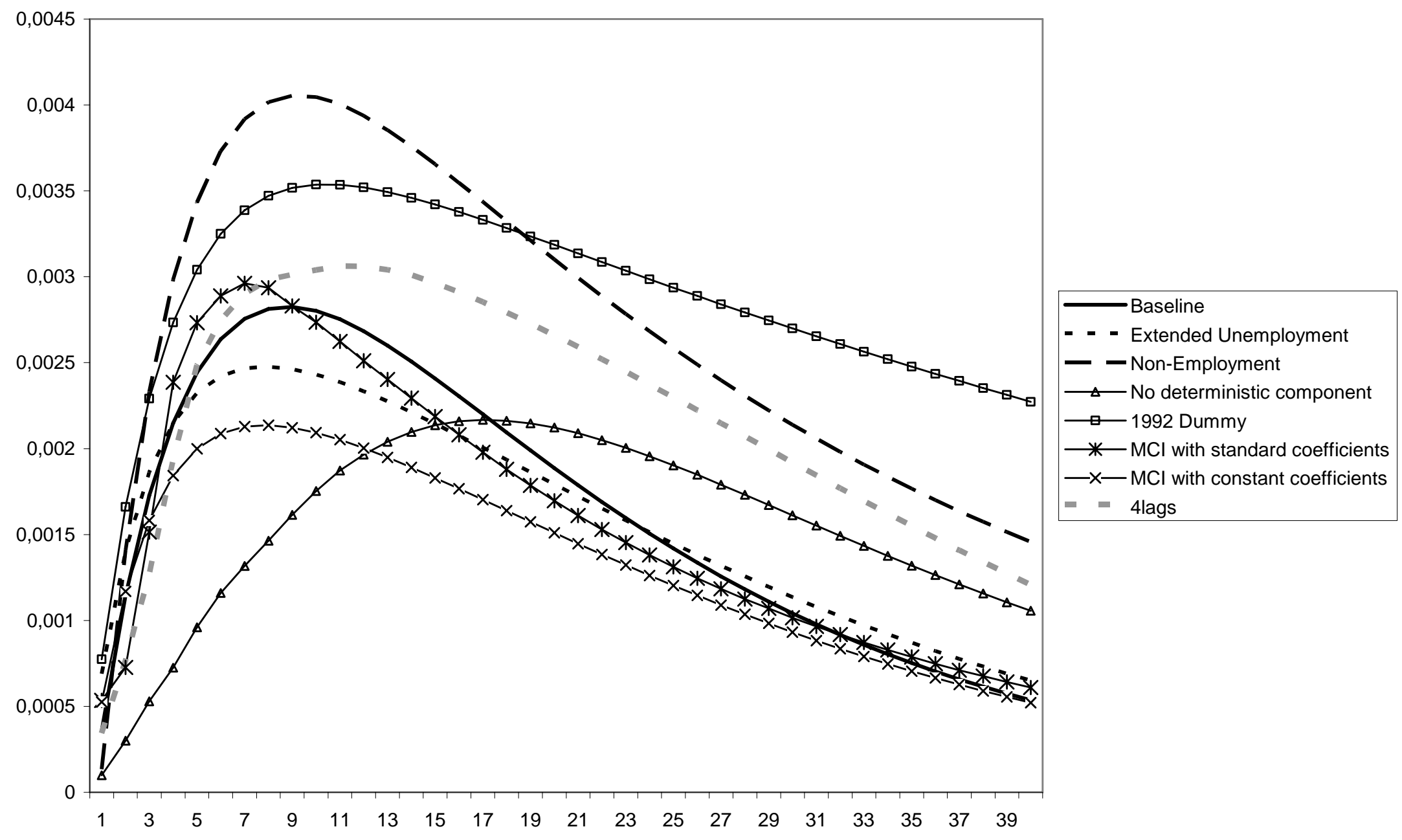

Note: The responses are calculated for a shock of one standard deviation. 
Table 3. Robustness checks.

\begin{tabular}{lcc}
\hline Specification & $\begin{array}{c}\text { FEVD 40 } \\
\text { quarters }\end{array}$ & $\begin{array}{c}\text { Share remaining after 10 } \\
\text { years }\end{array}$ \\
\hline Extended unemployment & 33.67 & 19.00 \\
Non-employment & 39.12 & 35.93 \\
1992 dummy rather than trend & 44.93 & 64.26 \\
Without trend and without 1992 dummy & 43.14 & 48.75 \\
4 lags in VAR & 38.45 & 39.44 \\
Constant coefficients in MCI & 27.01 & 20.59 \\
Standard coefficients and constant equilibria & 25.79 & 24.44 \\
in MCI & & \\
\hline Baseline & 34.42 & 28.10 \\
\hline
\end{tabular}

\section{Concluding Remarks}

Unemployment in Sweden remained low at 2-3 percent throughout the 1970s and the 1980s but hit double-digit levels in the early 1990s. It is likely that the rise in unemployment was partly driven by a series of adverse macroeconomic shocks, including a contractionary monetary policy as the Riksbank stubbornly defended the fixed exchanged rate. Institutional factors may also have played some role, although these are somewhat difficult to capture empirically.

Our paper focuses on the effects of monetary policy on Swedish unemployment fluctuations. To that end, we estimate a structural VAR model and find that between 22 and 35 percent of the fluctuations in unemployment are caused by shocks to monetary policy. The effects are also quite persistent. In the preferred model, around 30 percent of the effects of a shock still remain after ten years. As the major aspects of the model is varied across reasonable alternatives, the share of the maximum effect of a monetary policy shock that remains after ten years ranges between about 19 and 65 percent. While this maximum effect occurs already after five quarters in the U.S., the hump-shaped responses peak after 7-17 quarters in Sweden depending on the exact specification of the VAR. Hence monetary policy appears to have slightly larger and much more persistent effects on unemployment in Sweden than in the U.S. It is plausible that these differences reflect differences in labor market institutions rather than monetary policy. Employment protection legislation, in particular, is much more stringent in Sweden, a fact which is bound to increase unemployment persistence. 
The reaction of unemployment to monetary policy shocks is found to be different from and in particular much more persistent than the better documented reaction of the output gap to monetary policy shocks. Our estimates of the latter impulse response function are fairly consistent with stylized facts. The maximum effect of monetary policy on output occurs after 5 quarters, which is a standard finding. Half of the effect of the shock has disappeared after three years and the point estimate returns to zero after six years. The latter results imply slightly more persistence also in the output gap than what is typically observed although not nearly as much persistence as we document in case of the response of unemployment to monetary policy shocks. Hence it is not correct to view the reaction of unemployment to a shock as simply a mapping of the corresponding reaction of the output gap.

Although our study attributes a significant role to monetary policy, a more complete explanation of Swedish unemployment requires an understanding of the causes of the trend rise that we have taken as exogenous. This remains as an important (although difficult) issue for future research. A second interesting remaining question is whether the prolonged effects of monetary policy on unemployment are present also in other European countries.

\section{References}

Akerlof, G, W Dickens and G Perry (1996), The Macroeconomics of Low Inflation, Brookings Papers on Economic Activity, No. 1, 1-76.

Akerlof, G, W Dickens and G Perry (2000), Near-Rational Wage and Price Setting and the Long-Run Phillips Curve, Brookings Papers on Economic Activity, No. 1, 1-60.

Alexius, A and M Carlsson (2005), Measures of productivity and the business cycle, Review of Economics and Statistics v. 87, iss. 2, pp. 299-307.

Algan, Yann (2002), How Well Does the Aggregate Demand-Aggregate Supply Framework Explain Unemployment Fluctuations? A France-United States Comparison, Economic Modelling, v. 19, iss. 1, pp. 153-77.

Amisano, G and M Serati (2003), What Goes Up Sometimes Stays Up: Shocks and Institutions As Determinants of Unemployment Persistence, Scottish Journal of Political Economy, September 2003, v. 50, iss. 4, pp. 440-70. 
Blanchard, O and D Quah (1989), The Dynamic Effects of Aggregate Demand and Supply Disturbances, American Economic Review, 79:4, 654-673.

Carstensen, K and G Hansen (2000), Cointegration and Common Trends on the West German Labour Market, Empirical Economics, v. 25, iss. 3, pp. 475-93.

Chistoffel, K. and T. Linzert (2005), The Role of Real Wage Rigidity and Labor Market Frictions for Unemployment and Inflation Dynamics, European Central Bank Working Paper 556.

Dolado J and J Jimeno (1997), The Causes of Spanish Unemployment: A Structural VAR Approach, European Economic Review, July 1997, v. 41, iss. 7, pp. 1281-1307.

Fabiani, S, A Locarno, G P Oneto, and P Sestito (2001), The Sources of Unemployment Fluctuations: An Empirical Application to the Italian Case, Labour Economics, v. 8, iss. 2, pp. 259-89.

Gali, J (1999), Technology, Employment, and the Business Cycle: Do Technology Shocks Explain Aggregate Fluctuations, American Economic Review v. 89, iss.1, pp. 248-271.

Gambetti, L and B Pistoresi (2004), Policy Matters: The Long Run Effects of Aggregate Demand and Mark-Up Shocks on the Italian Unemployment Rate, Empirical Economics v. 29, iss. 2, pp. 209-26.

Holmlund, B (2003), The Rise and Fall of Swedish Unemployment, CESifo Working Paper 918.

Jacobson, T, A Vredin, and A Warne (1997), Common Trends and Hysteresis in Scandinavian Unemployment, European Economic Review v. 41, iss. 9, pp. 1781-1816.

Jacobson, T, P Jansson, A Vredin, and A Warne (2003), Identifying the Effects of Monetary Policy Shocks in an Open Economy, Sveriges Riksbank Working Paper No 153.

Karanassou, M., H. Sala, and D. Snower (2005), A Reappraisal of the Inflation-Unemployment Tradeoff, European Journal of Political Economy, v. 21, iss. 1, pp. 1-32.

L'Horty, Y and C Rault (2003), Why Is French Equilibrium Unemployment So High? An Estimation of the WS-PS Model, Journal of Applied Economics, v. 6, iss. 1, pp. 127-56

Lindé, J (2003), Monetary Policy Shocks and Business Cycle Fluctuations in a Small Open Economy: Sweden 1986-2002, Sveriges Riksbank Working Paper No 153.

Maidorn, S (2003), The Effects of Shocks on the Austrian Unemployment Rate - A Structural VAR Approach, Empirical Economics, v. 28, iss. 2, pp. 387-402.

Ravn, M and S Simonelli (2006), Labor Market Dynamics and the Business Cycle: Structural Evidence for the United States, manuscript, European University Institute. 
Sims, C (1980), Macroeconomics and Reality, Econometrica, v. 48, 1-48

Villiani, M and A Warne (2003), Monetary Policy Analysis in a Small Open Economy using Bayesian Cointegrated Structural VARs, Sveriges Riksbank Working Paper No 156. 
WORKING PAPERS*

Editor: Nils Gottfries

2006:17 Bertil Holmlund, Quian Liu and Oskar Nordström Skans, Mind the Gap? Estimating the Effects of Postponing Higher Education. 33pp.

2006:18 Oskar Nordström Skans, Per-Anders Edin and Bertil Holmlund, Wage Dispersion Between and Within Plants: Sweden 1985-2000. 57pp.

2006:19 Tobias Lindhe and Jan Södersten, The Equity Trap, the Cost of Capital and the Firm's Growth Path. 20pp.

2006:20 Annika Alexius and Peter Welz, Can a time-varying equilibrium real interest rate explain the excess sensitivity puzzle? 27pp.

2006:21 Erik Post, Foreign exchange market interventions as monetary policy. 34pp.

2006:22 Karin Edmark and Hanna Ågren, Identifying Strategic Interactions in Swedish Local Income Tax Policies. 36pp.

2006:23 Martin Ågren, Does Oil Price Uncertainty Transmit to Stock Markets? 29pp.

2006:24 Martin Ågren, Prospect Theory and Higher Moments. 31pp.

2006:25 Matz Dahlberg, Eva Mörk, Jørn Rattsø and Hanna Ågren, Using a discontinuous grant rule to idenitfy the effect of grants on local taxes and spending. 26pp.

2006:26 Jukka Pirttiläa and Håkan Selin, How Successful is the Dual Income Tax? Evidence from the Finnish Tax Reform of 1993. 40pp.

2006:27 Henrik Jordahl and Che-Yuan Liang, Merged Municipalities, Higher Debt: On Free-riding and the Common Pool Problem in Politics. 34pp.

2006:28 Per Engström, Ann-Sofie Kolm and Che-Yuan Liang, Maternal Addiction to Parental Leave. 18pp.

2006:29 Jonas Björnerstedt and Andreas Westermark, Delay in Bargaining with Externalities. 27pp.

2006:30 Pär Österholm, Incorporating Judgement in Fan Charts. 36pp.

2006:31 Mikael Carlsson and Andreas Westermark, Monetary Policy and Staggered Wage Bargaining when Prices are Sticky. 26pp.

2007:1 Mikael Elinder, Local Economies and General Elections. 26pp.

\footnotetext{
* A list of papers in this series from earlier years will be sent on request by the department.
} 
2007:2 Ouarda Merrouche, The Long Term Impact of French Settlement on Education in Algeria. 19pp.

2007:3 Ouarda Merrouche, The Long Term Effect of Education Spending Decentralization on Human Capital in Spain. 15pp.

2007:4 Erik Post, Macroeconomic imbalances and exchange rate regime shifts. 38pp.

2007:5 Christian Andersson, Teacher density and student achievement in Swedish compulsory schools. 31pp.

2007:6 Thomas Aronsson, Sören Blomquist and Luca Micheletto, Where Should the Elderly Live and Who Should Pay for their Care? A Study in Demographics and Geographical Economics. 22pp.

2007:7 Sören Blomquist and Vidar Christiansen, Public Provision of Private Goods and Nondistortionary Marginal Tax Rates. 17pp.

2007:8 Marcus Eliason and Henry Ohlsson, Living to Save Taxes. 13pp.

2007:9 Åsa Ahlin and Eva Mörk, Effects of decentralization on school resources: Sweden 1989-2002. 31pp.

2007:10 Henry Ohlsson, The equal division puzzle - empirical evidence on intergenerational transfers in Sweden. 20pp.

2007:11 Daniel Hallberg and Mårten Lagergren, Moving in and out of public geriatric care in Sweden. 26pp.

2007:12 Per Engström, Wage Formation and Redistribution. 22pp.

2007:13 Henry Ohlsson, Tax avoidance - a natural experiment. 21pp.

2007:14 David Kjellberg and Erik Post, A Critical Look at Measures of Macroeconomic Uncertainty. 27pp.

2007:15 Mikael Carlsson and Andreas Westermark, Optimal Monetary Policy under Downward Nominal Wage Rigidity. 52pp.

2007:16 Robin Douhan and Anders Nordberg, Is the elephant stepping on its trunk? The problem of India's unbalanced growth. 33pp.

2007:17 Annika Alexius and Bertil Holmlund, Monetary Policy and Swedish Unemployment Fluctuations. 27pp.

See also working papers published by the Office of Labour Market Policy Evaluation http://www.ifau.se/ 